канд. екон. наук, доцент кафедри страхування, Демченко B.O., асистент кафедри страхування, Державний вищий навчальний заклад «Київський національний економічний університет імені Вадима Гетьмана»

\title{
РОЗВИТОК РИНКУ СТРАХУВАННЯ ЖИТТЯ В УКРАЇНІ
}

\author{
Tretiak K.V., \\ cand.sc.(econ.), associate professor \\ at the department of insurance, \\ Demchenko V.O., \\ assistant at the department of insurance, \\ Kyiv National Economic University \\ named after Vadym Hetman
}

\section{DEVELOPMENT OF LIFE INSURANCE MARKET IN UKRAINE}

Постановка проблеми. Життя громадян кожної країни $є$ одним з найголовніших державних пріоритетів. Таким чином, кожна країна має приділяти достатньо уваги страхуванню життів свого населення [1]. На жаль, на сьогодні український ринок страхування життя є дуже відсталим. Більше того, населення України є доволі необізнаним в даному напрямку, а тому несвідомо нехтує цією можливістю. 3 кожним роком якісна медицина в Україні стає все більш дорожчою. Як результат, населення $є$ незахищеним як від простої вірусної інфекції, так і від хвороб, які несуть пряму загрозу життю.

Аналіз останніх досліджень і публікацій. Вітчизняний ринок страхування життя в контексті його фрункціонування та розвитку розглядається у працях багатьох науковців. Відмітимо, що найбільша кількість досліджень по даній тематиці виконана українськими вченими, серед яких можна виділити роботи [1-3], які дозволяють скласти уявлення про особливості ринку страхування життя. Прослідкувати динаміку фрункціонування даного сегменту можна на основі даних статистичних джерел України [4-7]. Ринок страхування життя $є$ також предметом постійних наукових і прикладних дискусій серед зарубіжних науковців та експертів [8-10]. Проте, багато авторів обмежуються оцінкою окремих сторін ринку страхування життя, що зумовлює необхідність проведення системного дослідження задля можливості ефективного функціонування ринку страхування життя.

Постановка завдання. Метою статті є дослідження основних проблем, з якими стикається вітчизняний ринок страхування життя, обґрунтування негативного впливу та визначення можливостей його подальшого розвитку.

Виклад основного матеріалу дослідження. Вже давно в світі страхування життя є одним 3 найголовніших напрямків страхування. Більшість розвинених країн світу мають відповідний високий рівень страхування життя. Однак, на сьогоднішній день, український ринок страхування життя $є$ не досить розвиненим в порівнянні з провідними країнами Європи та світу. Даний напрямок страхування потребує більшої уваги в Україні. Для визначення пріоритетних напрямків його розвитку потрібен розгляд сучасного стану ринку страхування життя в Україні, основних його переваг та недоліків, що надасть можливість визначити передумови для його розвитку.

Згідно зі статистичною інформацією «Нацкомфрінпослуг» за 2019 рік, загальна кількість страхових компаній (далі - СК) в Україні станом на 31.12.2019 становила 233, у тому числі СК "life" 23 компанії, СК "non-life" - 210 компаній, (станом на 31.12.2018 - 281 компанія, у тому числі СК "life" 30 компаній, СК "nonlife" - 251 компанія) (табл. 1).

3 наведених даних можна помітити, що кількість СК в Україні значно скоротилася; так, за 2019 рік порівняно з 2018 роком, кількість компаній зменшилася на 48 СК, а порівняно з 2017 роком - на 61 CK.

Розмір загальних валових страхових виплат за 2019 рік становив 14 338,3 млн грн, у тому числі зі страхування життя - 575,9 млн грн (або 4,0\%). За 12 місяців 2019 року сума отриманих 
страховиками валових премій зі страхування життя - 4624,0 млн грн (або 8,7\% від загальної суми страхових премій) (табл. 2).

Таблиця 1

Динаміка кількості страхових компаній в Україні за 2017-2019 рр.

\begin{tabular}{|c|c|c|c|}
\hline Кількість CK & 2017 & 2018 & 2019 \\
\hline Загальна & 294 & 281 & 233 \\
\hline CK «Non-life» & 261 & 251 & 210 \\
\hline CK «Life» & 33 & 30 & 23 \\
\hline
\end{tabular}

Джерело: складено авторами на основі $[4 ; 5 ; 6]$

Таблиця 2

Структура валових та чистих страхових премій за 2018-2019 рр.

\begin{tabular}{|c|c|c|c|c|c|c|}
\hline \multirow{3}{*}{ Види страхування } & \multicolumn{4}{|c|}{ Страхові премії, млн грн } & \multicolumn{2}{|c|}{ Темпи приросту, \% } \\
\hline & Валові & Чисті & Валові & Чисті & $\begin{array}{c}\text { Валових } \\
\text { премій }\end{array}$ & $\begin{array}{l}\text { Чистих } \\
\text { премій }\end{array}$ \\
\hline & \multicolumn{2}{|c|}{2018} & \multicolumn{2}{|c|}{2019} & \multicolumn{2}{|c|}{$2019 / 2018$} \\
\hline $\begin{array}{l}\text { Автострахування (КАСКО, } \\
\text { ОСЦПВ, «Зелена картка») }\end{array}$ & 12975,1 & 11720,7 & 15110,2 & 13801,2 & 16,5 & 17,8 \\
\hline Страхування життя & 3906,1 & 3906,1 & 4624,0 & 4624,0 & 18,4 & 18,4 \\
\hline $\begin{array}{ll}\text { Медичне } & \text { страхування } \\
\text { (безперервне } & \text { страхування } \\
\text { здоров'я) } & \\
\end{array}$ & 3486,7 & 3243,1 & 4470,3 & 4268,8 & 28,2 & 31,6 \\
\hline Страхування майна & 6440,2 & 3222,0 & 6604,8 & 3518,4 & 2,6 & 9,2 \\
\hline $\begin{array}{lcc}\text { Страхування } & \text { від } & \text { вогневих } \\
\text { ризиків та ризиків } & \text { стихійних } \\
\text { явищ } & & \\
\end{array}$ & 4497,1 & 1915,6 & 4746,3 & 2173,6 & 5,5 & 13,5 \\
\hline Страхування фрінансових ризиків & 5135,5 & 1663,8 & 4397,6 & 2151,2 & $-14,4$ & 29,3 \\
\hline Страхування медичних витрат & 1345,9 & 1098,8 & 1885,5 & 1685,9 & 40,1 & 53,4 \\
\hline $\begin{array}{l}\text { Страхування від нещасних } \\
\text { випадків }\end{array}$ & 1754,2 & 1329,0 & 1872,2 & 1475,3 & 6,7 & 11,0 \\
\hline Страхування вантажів та багажу & 2899,0 & 1479,3 & 2835,0 & 1432,3 & $-2,2$ & $-3,2$ \\
\hline $\begin{array}{l}\text { Страхування відповідальності } \\
\text { перед третіми особами }\end{array}$ & 2567,2 & 1659,7 & 2238,7 & 1424,3 & $-12,8$ & $-14,2$ \\
\hline Авіаційне страхування & 1041,7 & 778,5 & 703,7 & 551,1 & $-32,4$ & $-29,2$ \\
\hline Страхування кредитів & 1113,6 & 577,2 & 1102,3 & 366,3 & $-1,0$ & $-36,5$ \\
\hline Інші види страхування & 2205,2 & 1830,5 & 2410,6 & 2113,6 & 9,3 & 15,5 \\
\hline Всього & 49367,5 & 34424,3 & 53001,2 & 39586,0 & 7,4 & 15,0 \\
\hline
\end{tabular}

Джерело: складено авторами на основі [4; 5]

Приріст чистих страхових премій за 2019 рік з медичного страхування - +31,6\% або 1025,7 млн грн, страхування життя - +18,4\% або 717,9 млн грн, страхування медичних витрат - +53,4\% або 587,1 млн грн.

Розмір валових страхових виплат за 2019 рік становив 14 338,3 млн грн, у тому числі з видів страхування, інших, ніж страхування життя - 13 762,4 млн грн (або 96,0\%), зі страхування життя 575,9 млн грн (або 4,0\%) (табл. 3).

Збільшення чистих страхових виплат за 2019 рік (1 607,9 млн грн) відбулося за рахунок суттєвого збільшення чистих страхових виплат за договорами автострахування на 880,4 млн грн, медичного страхування - 507,9 млн грн, страхування фрінансових ризиків - 176,8 млн грн. Водночас, спад чистих страхових виплат спостерігався зі страхування майна на 265,6 млн грн, страхування життя - 129,0 млн грн.

Структура чистих страхових виплат станом на 31.12.2019 р. перерозподілилася на користь медичного страхування (з 16,9\% до 18,5\%), автострахування (з 45,2\% до 46,3\%), страхування вантажів та багажу (з 1,0\% до 1,5\%) за рахунок зменшення частки страхування майна (з 11,4\% до $8,2 \%)$, страхування життя (3 5,7\% до 4,1\%). 
Валові страхові платежі (премії, внески) при страхуванні життя за 2019 рік становили 4 624,0 млн грн, що на 18,4\% більше, ніж за 2018 рік (станом на 31.12.2018 - 3 906,1 млн грн). Структура надходжень валових страхових платежів (премій, внесків) станом на 31.12.2019 має такий вигляд: 4 490,8 млн грн (або 97,1\%), що надійшли від фрізичних осіб; 133,2 млн грн (або 2,9\%), що надійшли від юридичних осіб. За 2019 рік збільшилася кількість застрахованих фрізичних осіб на $14,7 \%$ або на 659138 осіб (станом на 31.12.2018 застраховано 4473911 фізичних осіб, станом на 31.12.2019 5133049 фізичних осіб). Протягом 2019 року застраховано 4596863 фрізичні особи, що на 52,4\% або на 1580252 особи більше проти відповідного періоду 2018 року (за 2018 рік застраховано 3016611 фізичних осіб). 3 наведеної таблиці 3 можемо проаналізувати динаміку щодо обсягів надходжень валових страхових платежів та валових страхових виплат зі страхування життя за 2017-2019 роки. Обсяг валових страхових виплат із страхування життя за 2019 рік становив 575,9 млн грн, що на 18,3\% менше в порівнянні з 2018 роком (704,9 млн грн).

\section{Структура страхових виплат за 2018-2019 рр.}

Таблиця 3

\begin{tabular}{|c|c|c|c|c|c|c|}
\hline \multirow{3}{*}{ Види страхування } & \multicolumn{4}{|c|}{ Страхові виплати, млн. грн. } & \multicolumn{2}{|c|}{ Темпи приросту, \% } \\
\hline & \multicolumn{2}{|c|}{ Валові } & \multicolumn{2}{|c|}{ Чисті } & $\begin{array}{c}\text { Валових } \\
\text { виплат }\end{array}$ & $\begin{array}{l}\text { Чистих } \\
\text { виплат }\end{array}$ \\
\hline & 2018 & 2019 & 2018 & 2019 & 201 & 18 \\
\hline Страхування життя & 704,9 & 575,9 & 704,9 & 575,9 & $-18,3$ & $-18,3$ \\
\hline Інші, ніж страхування життя & 12158,5 & 13762,4 & 11727,7 & 13464,6 & $13,2 \%$ & 14,8 \\
\hline Всього & 12863,4 & 14338,3 & 12432,6 & 14040,5 & 11,5 & 12,9 \\
\hline
\end{tabular}

Джерело: складено авторами на основі [4; 5]

Станом на 31.12.2019 величина зміни резервів із страхування життя становила 1 016,9 млн грн, що на 1,4 млн грн менше у порівнянні 3 попереднім роком та на 33,9 млн грн більше у порівнянні 3 відповідним періодом 2017 року. Основна частина величини зміни резервів зі страхування життя сформована за іншими договорами накопичувального страхування, а саме - 898,9 млн грн. За підсумками 2019 року 7 CK "Life" отримали від'ємне значення приросту резервів із страхування життя на загальну суму $76,1 \mathrm{mлн} \mathrm{грн,} \mathrm{що} \mathrm{пов'язано} \mathrm{з} \mathrm{достроковим} \mathrm{розірванням} \mathrm{договорів} \mathrm{страхування} \mathrm{(за}$ підсумками 2018 року від'ємне значення задекларували 8 CK "Life" на загальну сумy 60,9 млн грн). Приріст резервів із страхування життя становив 1093,0 млн. грн. Найбільший приріст страхових резервів зі страхування життя (більше 100 млн грн) відображено чотирма страховими компаніями "Life" у розмірах 574,3 млн грн, 169,6 млн грн, 146,4 млн грн та 122,3 млн грн (52,5\%, 15,5\%, 13,4\% та $11,2 \%$ від загального приросту резервів відповідно).

Доречно буде порівняти цифрри України та показники розвинутих Європейських країн (рис. 1).

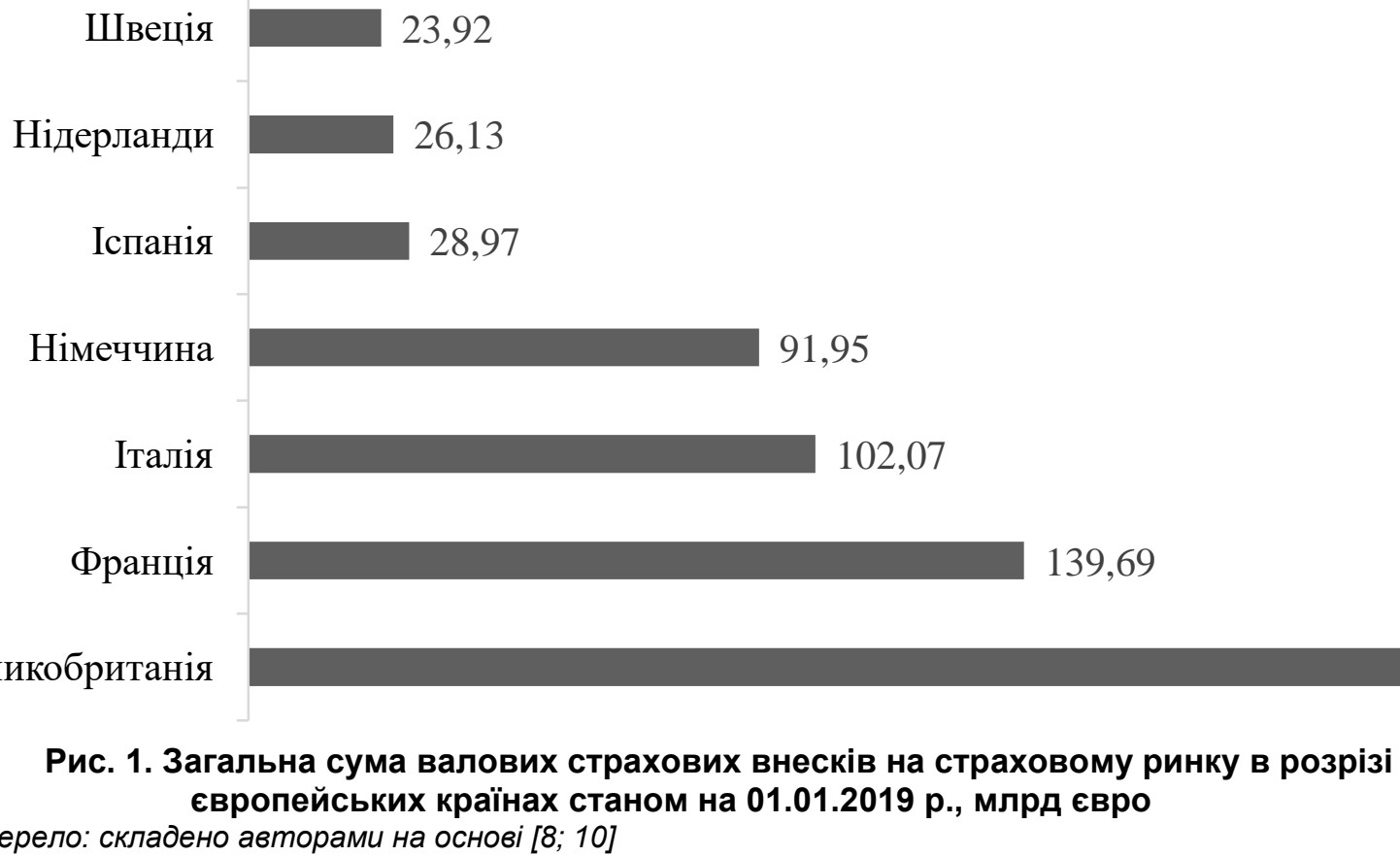

Джерело: складено авторами на основі [8; 10] 
Так, практика розвинутих європейських країн показує, що страхування життя займає майже половину всіх страхових виплат в країні [8; 10]. Наприклад, у Франції за 2017 рік показник страхових премій сягнув майже 207000 млн євро, з яких понад 129000 млн євро становили премії зі страхування життя. В той же час у Німеччини дані показники відповідали значенням: 246000 млн євро та 115 млн євро відповідно. Отже, можна сказати, що у провідних країнах Європи страхування життя $є$ одним з ключових видів страхування.

Як видно з даних рис. 1, станом на 01 січня 2019 року серед лідерів за валовими преміями на страховому ринку - Великобританія (229,89 млрд. євро), Франція (139,69 млрд. євро) та Італія (102,07 млрд. євро) [10].

Питання включення страхових послуг у соціальні програми нині набуває актуальності й у багатьох розвинених країнах світу у зв'язку з переважанням серед населення кількості людей похилого віку, а також великої кількості працівників на підприємствах із високими ризиками [7]. Уряди цих країн своїми діями стимулюють участь компаній зі страхування життя у розвитку програм довгострокового накопичення для забезпечення старості.

Однак, наразі ринок України є досить відсталим в порівнянні з ринками розвинутих європейських країн. Перш за все, такий розрив можна пояснити рівнем розвитку фінансового ринку. Так, розвиток фрінансових ринків за кордоном $є$ дійсно вищим, ніж в Україні. Тому з розвитком фрінансового ринку можна буде очікувати і розвитку ринку страхування.

По-друге, досить важливу роль відіграє стабільність як економіки, так і валюти в кожній країні. На сьогодні економіка України та гривня не можуть на гідному рівні конкурувати з провідними країнами Європи. Знову ж таки при поліпшенні цих двох фракторів страховий ринок України може чекати значний розвиток.

Третім фрактором, безперечно, можна назвати те, що ментально більшість громадян України звикли до безкоштовної медицини, яка була за радянських часів і залишається досі. Якщо в Європі майже всі підприємства мають застрахованих працівників, то в Україні лише великі або міжнародні компанії страхують своїх працівників.

Нині розвиваються два напрями страхування життя: накопичувальне пенсійне та страхування від нещасних випадків на виробництві, що включаються підприємствами в соціальний пакет. Із 2019 р. в Україні на державному рівні впроваджене накопичувальне пенсійне страхування. Прогнозується, що страховики, які мають подібні програми, активно підхоплять цю ініціативу, пропонуючи вигідніші умови, ніж державні. Поки державна програма знаходиться на стадії впровадження, пенсіонери, які бажають мати достойну пенсію, можуть вибирати між накопичувальним та інвестиційним страхування життя або звернутися до недержавних пенсійних фондів.

Також слід зазначити, що кількість застрахованих громадян перевищує кількість договорів страхування. Це пояснюється тим, що в Україні наявне корпоративне страхування життя, пов'язане 3 укладенням колективних договорів страхування, які входять до складу соціального пакету. У поточних умовах соціальний пакет є одним із необхідних складників системи управління організацією. Найвищу активність у наданні соціальних пакетів проявляє сектор FMCG, IT і телекомунікації та фрінансовий сектор (переважно банки та консалтингові компанії). Соціальний пакет здебільшого надають компанії 3 іноземним капіталом та з чисельністю персоналу від 100 до 500 осіб, тобто реально великі міжнародні компанії. Знову ж таки слід зазначити, що цей тренд приходить в Україну саме з розвинутих західних країн.

У нинішніх економічних умовах України значимість соціального пакета загострилася. У попередні часи він використовувався для залучення гідних фрахівців та утримання найкращих співробітників, проте нині провідна роль спрямована на збереження задоволеності й лояльності персоналу.

До складу соціального пакета включають як базові соціальні гарантії, передбачені законодавством про працю та соціальне забезпечення, так і додаткові матеріальні блага, надання яких здійснюється роботодавцем за власною ініціативою, серед них значну частку відводять на різноманітні види страхування. Види страхування, які пропонуються на ринку страхування України для включення до соціального пакету: добровільне медичне страхування працівників; корпоративне страхування життя; страхування здоров'я на випадок хвороби; страхування працівників від нещасних випадків; туристичне страхування для юридичних осіб. Укладення договору страхування життя та здоров'я персоналу - звичайна практика у розвинених країнах Європи та світу, адже наявність страхового захисту чи пенсійної програми, виплати за якими здійснюються понад гарантовані державою стандарти, є суттєвою частиною соціального компенсаційного пакету підприємства та вигідно вирізняє такого роботодавця серед інших конкурентів на ринку праці [9]. 3 іншого боку, працівник, що має оплачене підприємством страхування, почувається більш захищеним, має додаткову мотивацію до праці та є більш лояльним.

Поступово в Україні все йде до того, що безкоштовної медицини стає все менше і менше. Також не слід забувати, що державні медичні послуги на сьогодні $€$ менш якісними в порівнянні 3 приватними. Тому якісний соціальний пакет, який надається роботодавцем, вирішує багато проблем як страховиків, так і страхувальників, а крім того й роботодавців. Але для гарантованого отримання 
обіцяних послуг необхідне офріційне працевлаштування, що $є$ однією з важливих проблем у державі. Для вирішення цієї проблеми необхідна реорганізація всієї системи працевлаштування, але найбільш результативним показником стане стійка економічна система держави.

Висновки з проведеного дослідження. Як висновок слід сказати, що ринок страхування життя в Україні поступово розвивається, однак значно відстає від європейського. По-перше, це пов'язане з менталітетом населення України, по-друге, з фракторами нестабільності економіки та гривні.

Перший фрактор є наслідком з радянських часів, коли медицина була надто доступною і не відрізнялася якістю. Однак на сьогодні приватні клініки $є$ платними і все ж таки надають набагато якісніші послуги. Явище корпоративного медичного страхування все більше приходить в Україну від західних країн-сусідів. Водночас, таким страхуванням користуються лише великі міжнародні підприємства, а також держслужбовці. Дуже важливим фрактором $є$ великий відсоток тіньової економіки, яка не дозволяє в повному обсязі використовувати працівникам якісне медичне страхування життя.

Дуже вдалим є підхід, коли держава бере на себе відповідальність за збереження мінімальних доходів усіх громадян і водночас максимально стимулює розвиток різних форм недержавного страхування з метою збереження життя, здоров'я та підвищення їхніх доходів. Яскраві приклади такої адаптованої системи демонструють країни Східної Європи: Польща, Чехія, Угорщина, Словаччина та iH.

Потенціал розвитку українського ринку страхування життя, за свідченнями аналітиків, дуже великий. Однак Україна потребує значного реформування як зі сторони медицини, так і зі сторони законів щодо працевлаштування. Люди мають звикати до отримання якісної та платної медицини. Також поштовхом до подальшого зростання ринку страхування життя виступатиме можливе нововведення Національного банку щодо створення системи гарантування виплат за договорами довгострокового страхування життя [11]. Прогнозовано, що впровадження нової моделі регулювання та нагляду за ринком страхування життя сприятиме досягненню багатьох цілей, а саме: підвищенню рівня капіталізації, ліквідності та стійкості страхових компаній; диверсифікації страхових послуг та посиленню конкуренції на ринку страхування життя; забезпеченню високих стандартів захисту прав страхувальників; прозорості функціонування ринку та підвищенню його привабливості для інвесторів. Наведені трансформації забезпечать підвищення довіри споживачів до ринку страхування життя та його більш глибоке проникнення на ринок фінансових послуг.

\section{Література}

1. Лобова О. М., Кудря М. Г. Тенденції страхування життя в Україні. Финансовые услуги. 2017. № 2. C. 27-33.

2. Волохова Л. Ф. Зарубіжний досвід розвитку ринку страхування життя як чинник впливу на українські реалії. Науковий вісник Міжнародного гуманітарного університету. Серія: Економіка $i$ менеджмент. 2019. Вип. 35. С. 137-142.

3. Летняк С. П. Стан і перспективи розвитку ринку страхування життя в Україні. Наукові записки Національного університету "Острозька академія». Серія: Економіка. 2019. № 12. С. 119-123.

4. Національна комісія, що здійснює державне регулювання у сфері фрінансових послуг. Консолідовані звітні дані про страховий ринок України 2019 року. URL: https://www.nfp.gov.ua/files/OgliadRinkiv/SK/sk_2019.pdf (дата звернення: 20.04.2020).

5. Національна комісія, що здійснює державне регулювання у сфері фрінансових послуг. Консолідовані звітні дані про страховий ринок України 2018 року. URL: https://www.nfp.gov.ua/files/OgliadRinkiv/SK/sk_2018.pdf (дата звернення: 20.04.2020).

6. Національна комісія, що здійснює державне регулювання у сфері фрінансових послуг. Консолідовані звітні дані про страховий ринок України 2017 року. URL: https://www.nfp.gov.ua/files/OgliadRinkiv/SK/sk_2017.pdf (дата звернення: 20.04.2020).
7. Глобальна платформа бізнес-даних
№ 1.
URL: https://www.statista.com/statistics/820909/insurance-total-gross-written-life-premiums-european-countries/ (дата звернення: 20.04.2020).

8. European Insurance in Figures - 2018 data. Insurance Europe. December 2019. 52 p. URL: https://www.insuranceeurope.eu/sites/default/files/attachments/European\%20Insurance\%20in\%20Figures\% 20-\%202018\%20data.pdf (дата звернення: 20.04.2020).

9. Ibbotson Roger G., Chen Peng, Milevsky Moshe Arye, Zhu Xingnong. Human Capital, Asset Allocation, and Life Insurance. Yale ICF Working Paper. May 2005. No. 05-11. URL: https://ssrn.com/abstract=723167 (дата звернення: 20.04.2020).

10. World International Insurance Fact Book 2020. International Insurance Institute. 2020. 242 p. URL: https://www.iii.org/sites/default/files/docs/pdf/insurance_factbook_2020.pdf (дата звернення: 20.04.2020). 
11.Національний банк України. Майбутнє регулювання ринку страхування. URL: https://bank.gov.ua/admin_uploads/article/White_paper_insurance_fin_pr_2020-04-22.pdf?v=4 (дата звернення: 23.04.2020).

\section{References}

1. Lobova, O.M. and Kudria, M.H. (2017), "Trend of life safety in Ukraine", Finansovye uslugi, no. 2, pp. 27-33.

2. Volohova, L.F. (2019), "Foreign experience in the development of the life insurance market as a factor influencing Ukrainian realities", Naukovyi visnyk Mizhnarodnoho humanitarnoho universytetu. Seriia: Ekonomika i menedzhment, Iss. 35, pp. 137-142.

3. Letniak, S.P. (2019), "Current state and prospects for the development of the market of life in Ukraine", Naukovi zapysky Natsionalnoho universytetu "Ostrozka akademiia". Seriia: Ekonomika, Iss. 12, pp. 119-123.

4. "The National Commission, carrying out state regulation in the field of financial services. Consolidated reporting data on the insurance market of Ukraine in 2019", available at: https://www.nfp.gov.ua/files/OgliadRinkiv/SK/sk_2019.pdf (access date 20 April 2020).

5. "The National Commission, carrying out state regulation in the field of financial services. Consolidated reporting data on the insurance market of Ukraine in 2018", available at: https://www.nfp.gov.ua/files/OgliadRinkiv/SK/sk_2018.pdf (access date 20 April 2020).

6. "The National Commission, carrying out state regulation in the field of financial services. Consolidated reporting data on the insurance market of Ukraine in 2017", available at: https://www.nfp.gov.ua/files/OgliadRinkiv/SK/sk_2017.pdf (access date 20 April 2020).

7. "Global platform of business data № 1", available at: https://www.statista.com/statistics/820909/insurance-total-gross-written-life-premiums-european-countries/ (access date 20 April 2020).

8. European Insurance in Figures - 2018 data, Insurance Europe, December 2019, 52 p., available at: $\quad$ https://www.insuranceeurope.eu/sites/default/files/attachments/EuropeanInsuranceinFigures-2018 data.pdf (access date 20 April 2020).

9. Ibbotson, Roger G., Chen, Peng, Milevsky, Moshe Arye and Zhu, Xingnong (2005), "Human Capital, Asset Allocation, and Life Insurance", Yale ICF Working Paper, Iss. 5-11, available at: https://ssrn.com/abstract=723167 (access date 20 April 2020).

10. International Insurance Institute (2020), World International Insurance Fact Book 2020, 242 p., available at: https://www.iii.org/sites/default/files/docs/pdf/insurance_factbook_2020.pdf (access date 20 April 2020).

11. National Bank of Ukraine (2020), "Future regulation of the insurance market", available at: https://bank.gov.ua/admin_uploads/artisle/White_paper_insuranse_fin_pr_2020-04-22.pdf?v=4 (access date 23 April 2020). 